\title{
The Influence of Heated Soil in Crop of "Tamaris" Tomato Plants on the Biological Activity of the Rhizosphere Soil
}

\author{
Lidia Sas Paszt, Paweł Trzciński, Małgorzata Bakalarska, Ryszard Hołownicki, \\ Paweł Konopacki, Waldemar Treder \\ Research Institute of Horticulture, Skierniewice, Poland \\ Email: Lidia.Sas@inhort.pl
}

Received 3 February 2014; revised 2 March 2014; accepted 9 March 2014

Copyright (C) 2014 by authors and Scientific Research Publishing Inc.

This work is licensed under the Creative Commons Attribution International License (CC BY).

http://creativecommons.org/licenses/by/4.0/

c) (i) Open Access

\begin{abstract}
The aim of this study was to evaluate the effect of heated soil on the population of bacteria, fungi and nematodes inhabiting the soil of tomato cultivar "Tamaris" growing in peat and coconut substrates. In addition, these media were tested in two different containers: cylinders and slabs. The total number of bacteria and fungi was significantly higher in the peat substrate than in the coconut substrate. A much higher number of beneficial bacteria producing spores were noted in the coconut soil. The total number of bacteria and fungi was modified by the heating levels. In all the experimental treatments, most of the identified individuals belonged to the group of nematodes that feed on bacteria and it was the most diverse group of species. The highest total number of nematodes was recorded for the second heating level, with the exception of cultivation carried out in peat slabs, where the most of nematodes were found at the control level. The highest first crop was produced by plants growing on the peat slabs supplied with the highest soil temperature. Tomato roots of all the control treatments showed the highest root morphological parameters.
\end{abstract}

\section{Keywords}

Heated Soil; Root Morphology; Tomato; Peat; Coconut Fibre; Cylinder; Slab; Bacteria; Fungi; Nematodes

\section{Introduction}

Tomato is a plant with high heat requirements and sensitive to cold weather and frost. The optimum temperature for the growth of tomato plants is between $21^{\circ} \mathrm{C}$ and $27^{\circ} \mathrm{C}$ during the day and between $17^{\circ} \mathrm{C}$ and $21^{\circ} \mathrm{C}$ at night 
[1]. The soil temperature is very important for plant growth. The optimum soil temperature for tomato cultivation should be within the range $15^{\circ} \mathrm{C}-18^{\circ} \mathrm{C}$. The proper development of the root system depends on the optimal temperature of the soil. A temperature below $14^{\circ} \mathrm{C}$ reduces and inhibits the growth of the root system and encourages the development of fungal and bacterial diseases. However, a soil temperature higher than the air temperature promotes excessive vegetative growth, causing delays in flowering, and even shedding of buds and fruits, especially these from the first cluster.

The rhizosphere is a region of intense microbial activity and all nutrients that plants absorb from soil must pass through this region. Changes in the rhizosphere might affect the rhizosphere microflora and, in turn, plant growth. Soil microorganisms are the first to respond to environmental changes. Therefore, for an overall assessment of changes taking place in a heated soil, the total numbers of bacteria, fungi and actinomycetes were subjected to detailed studies at different periods of plant development [2]. The need for this research was due to the fact that any change in a physicochemical parameter of soil is reflected as a change in the processes that stimulate the biological activity of the soil. The studies done so far in a heated substrate show that the biological activity of soil microorganisms changed significantly as a result of the thermal factor. An evaluation of soil activity was carried out for "Tamaris" tomato plants at different heating temperatures supplied to the soil [3]. The biological activity of the rhizosphere soil was determined at four stages of plant development: at the beginning of flowering (V-May), at the beginning of fruiting (VI-June), during full fruiting (VII-July) and at the end of experiment (X-October).

The experiment was established in a greenhouse of the Research Institute of Horticulture in Skierniewice in April 2012 and completed in October 2012. The aim of this study was to evaluate the influence of heated soil (at three heating temperatures) on the population of bacteria, fungi and nematodes inhabiting the rhizosphere soil of tomato plants of the cultivar "Tamaris" growing in peat and coconut substrates [4] [5].

\section{Materials and Methods}

\subsection{Experimental Treatment}

The peat and coconut substrates were tested at the following heating levels:

$\mathbf{1}^{\text {st }}$ level without heating - control level, unheated substrate.

$2^{\text {nd }}$ heating level—air temperature applied to a substrate was between $17^{\circ} \mathrm{C}$ and $20^{\circ} \mathrm{C}$.

$3^{\text {rd }}$ heating level-air temperature applied to a substrate was set in the range from $25^{\circ} \mathrm{C}$ to $30^{\circ} \mathrm{C}$.

The heating was turned off when the night temperature exceeded $17^{\circ} \mathrm{C}$.

The experiment was carried out in 12 treatments and in 3 replications (one slab was one replication). Tomato plants cv. Tamaris were growing in peat and coconut substrates. These soils were tested in two different types of containers (see Figure 1): cylinders (each of 5 L capacity) and slabs (each of 20 L capacity).

Plant nutrition was done automatically. The amount and frequency of dosing the medium varied in different periods and phases of the growth of tomato plants and depended on the external conditions such as sunlight and air temperature. The mixtures of fertilizers such as calcium nitrate, potassium, magnesium sulfate, potassium sulfate, potassium phosphate, microelements and nitric acid were used for feeding plants.

The plant nourishment was controlled by electrical conductivity—EC and $\mathrm{pH}$. The experiment included the following experimental treatments:
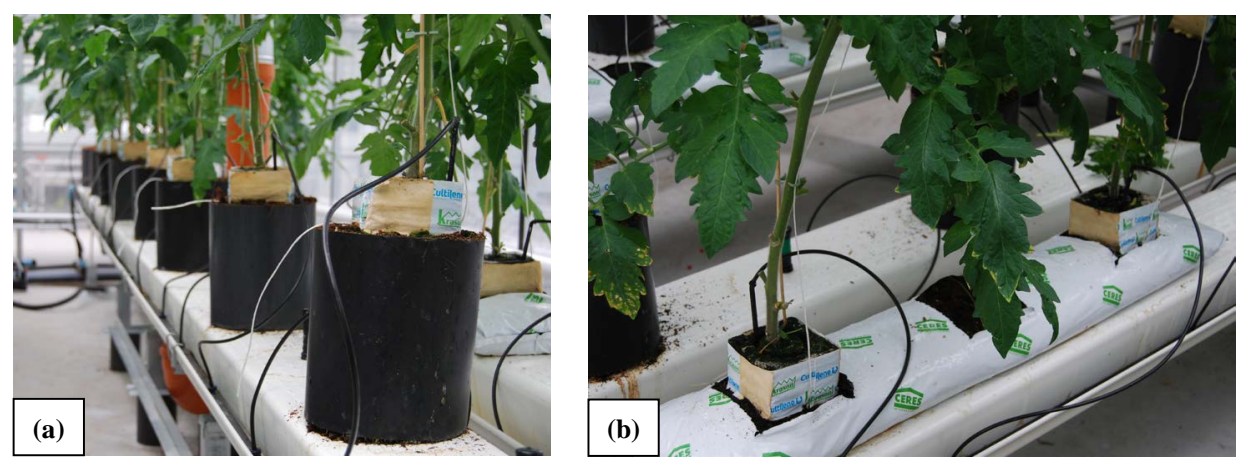

Figure 1. Tomato plants growing in (a) cylinders and in (b) slabs. 
1) $\mathrm{L} 1-1^{\text {st }}$ heating level—control treatment—cylinders with peat substrate.

2) L2-2 ${ }^{\text {nd }}$ heating level—cylinders with peat substrate.

3) L3- ${ }^{\text {rd }}$ heating level—cylinders with peat substrate.

4) $\mathrm{L} 1-1^{\text {st }}$ heating level— control treatment- - slabs with peat substrate.

5) $\mathrm{L} 2-2^{\text {nd }}$ heating level—slabs with peat substrate.

6) L3-3 $3^{\text {rd }}$ heating level—slabs with peat substrate.

7) L1- ${ }^{\text {st }}$ heating level—control treatment-cylinders with coconut substrate.

8) L2-2 ${ }^{\text {nd }}$ heating level—cylinders with coconut substrate.

9) L3-3 $3^{\text {rd }}$ heating level—cylinders with coconut substrate.

10) L1- ${ }^{\text {st }}$ heating level— control treatment—slabs with coconut substrate.

11) L2-2 ${ }^{\text {nd }}$ heating level—slabs with coconut substrate.

12) $\mathrm{L} 3-3^{\text {rd }}$ heating level—slabs with coconut substrate.

\subsection{Yielding of Plants}

In the vegetation period, plant yield was recorded and calculated per number of plants [6].

\subsection{Determination of Root Growth and Morphological Parameters}

- fresh and dry root weight [7].

- root morphological parameters (total root length, root diameter, root volume, root surface area and total number of root tips) - image analysis system with an Epson scanner, controlled by WinRhizo software (Regent Instruments Inc.).

\subsection{Microbiological Analysis of Soil}

Dynamics of development of selected microbial groups was determined at four monthly intervals, depending on the development phase of tomato:

- V-May, beginning of flowering.

- VI-June, beginning of fruiting.

- VII-July, full fruiting.

- X-October, last harvest and removal of plants.

In bulk samples collected from the rhizosphere of all experimental treatments, the numbers of microorganisms were determined using the plate method on selective agar media (in four replications). Mean number of colonies were given per fresh matter of a given substrate:

- total bacterial number with the number of bacteria producing spores were determined on a nutrient agar medium after 5 - 10 days of incubation at $28^{\circ} \mathrm{C}$.

- total fungal count was determined on Rose Bengal Chloramphenicol Agar medium after 5 - 7 days of incubation at $25^{\circ} \mathrm{C}$.

- the number of actinomycetes were determined on actinomycetes Isolation Agar and Water Agar media after 14 - 21 days of incubation at $26^{\circ} \mathrm{C}$.

To calculate the number of microorganisms only the plates with colonies between 30 and $300 \mathrm{CFU}$ were taken into account.

\subsection{Nematological Analysis of Soil}

Samples consisted of $100 \mathrm{~g}$ of soil with roots. Because of the significant share of roots in a sample, the material had to be cut into smaller pieces. Nematodes were isolated by the Baermann method on a sieve for 48 hours. The isolated nematodes were preserved in $20 \mathrm{ml}$ of TAF mixture.

\subsection{Statistical Analysis}

The results were statistically evaluated (analyzed by) with multivariate analysis of variance verifying the hypothesis of equality of means $\left(\mathrm{H}_{0}: \mathrm{x}_{1}=\mathrm{x}_{2}=\mathrm{x}_{3}\right)$ at significance level 0.05 . It was done by Statistica software, version 10 (StatSoft Inc., 2012). 


\section{Results and Discussion}

\subsection{Crop}

The very first harvest of tomatoes was about 30 days after flowering. Plants from the third heating level were the first that cropped. The tomato plants growing on the peat substrate produced the first crop (e.g. the number of fruits produced during the first week of cropping) earlier than the plants planted in the coconut substrate. The highest first crop was produced by plants growing on the peat slabs supplied with the highest soil temperature (the $3^{\text {rd }}$ heating level, see Figure 2). This indicates a positive influence of peat as a growth substrate inserted in slabs on the yielding potential of tomato plants. The effect was due to the significantly higher levels of organic matter, N-NO $3\left(168 \mathrm{mg} / \mathrm{dm}^{3}\right), \mathrm{N}^{-N_{4}}\left(123 \mathrm{mg} / \mathrm{dm}^{3}\right)$, and high levels of P $\left(164 \mathrm{mg} / \mathrm{dm}^{3}\right)$, Ca $\left(727 \mathrm{mg} / \mathrm{dm}^{3}\right)$ and microelements (Fe-2.6 mg/dm ${ }^{3}$, Mn-5,1 mg/dm ${ }^{3}$ ) in comparison to coconut.

The total yield (the yield from the whole experimental period) didn't differ significantly for all experimental treatments (see Figures 3(a) and (b)). However, it could be noticed that the crop of tomato plants growing in the cylinders filled with coconut fibre and slabs filled with peat slightly increased with increasing soil temperature. This indicates that irrespective of the growth substrate, the higher temperature increased the nutritional status of the plants, their shoot growth parameters, green colour of the leaves and subsequent yielding. Tomato plants growing in cylinders with peat and in slabs with coconut fibre gave comparable total yield for all heating levels. The tomato plants planted in coconut cylinders and in peat slabs at the third heating level gave the highest total yields. It is therefore suggested that the highest temperature of $25^{\circ} \mathrm{C}$ (higher by about $15^{\circ} \mathrm{C}$ at the $3^{\text {rd }}$ heating level in comparison with the control: $10^{\circ} \mathrm{C}$ ) had the most accelerating influence on the yielding potential of the plants. This was due to the enhanced nutrient uptake and acquisition, and higher energy and water supply to the plants.

\subsection{Root Morphological Analysis}

The soil temperature didn't have a significant impact on the growth of the tomato root system (Figure 4(a)). Although, tomato roots of all the control treatments showed the highest root morphological parameters. Figure 4 presents only the results of the root volume, but the same results were also obtained for the root surface area, the root diameter and the root fresh weight. The statistical analysis showed that there was the significant influence of the container shape and the interaction between the container shape and the substrate type on the root system growth (Figures 4(b) and (d)). Tomato roots growing in peat cylinders were significantly longer, had a bigger volume and surface area than those of the roots growing in peat and coconut slabs (Figure 4(d)). This indicates that in comparison with slabs, the cylinder-shaped containers provided better aeration conditions to the plants and allowed the plants to grow better and form roots with a greater length, volume and surface area. It was also clearly visible that in the cylinders tomato roots grew horizontally (according to the natural geotropism), whereas in the slabs root growth was directed more vertically with a lower oxygen supply. Therefore, the root

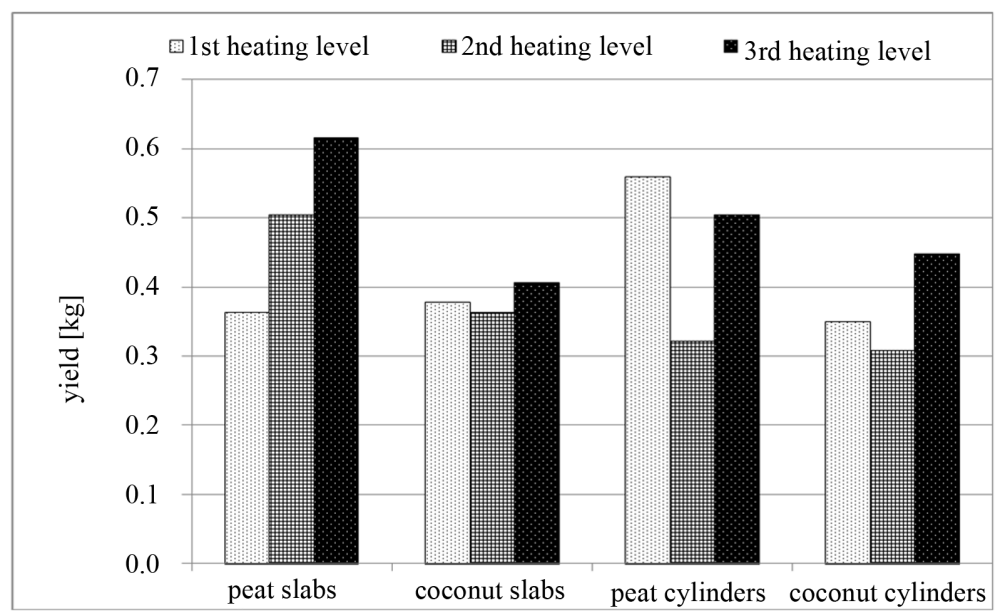

Figure 2. The first weekly crop of tomato plants growing in a greenhouse against the heating level. 

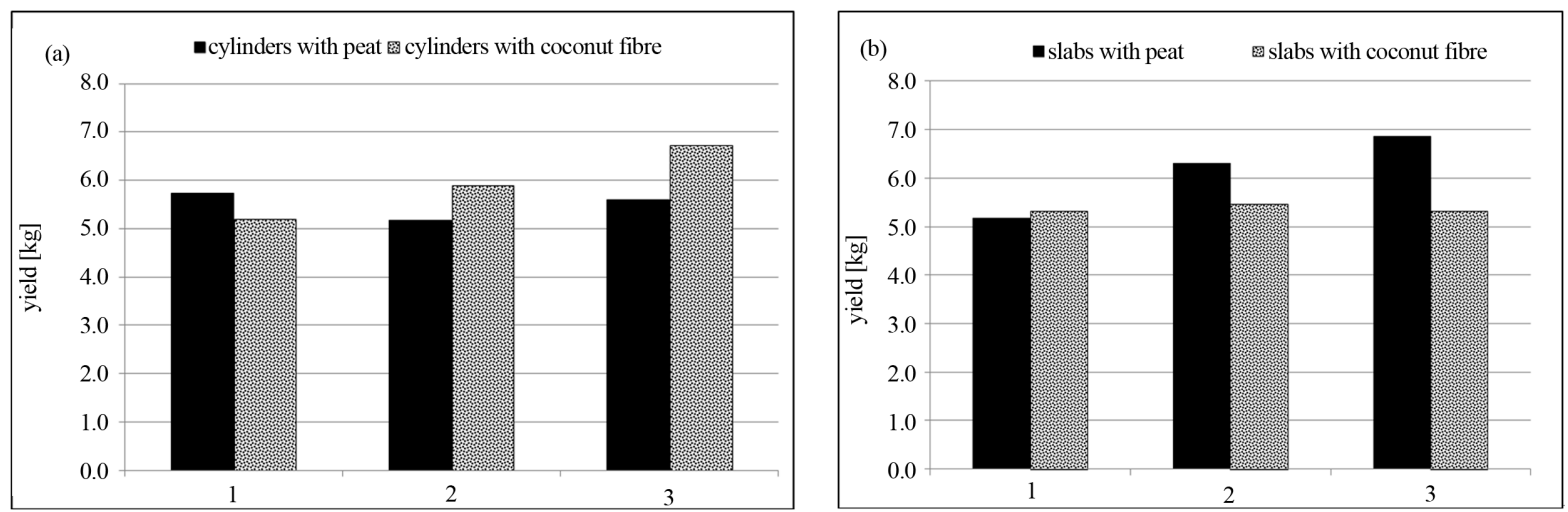

Figure 3. Total yield produced by tomato plants growing in (a) cylinders and (b) slabs against the heating level. 1-Control level, 2 —second heating level, 3 — third heating level.

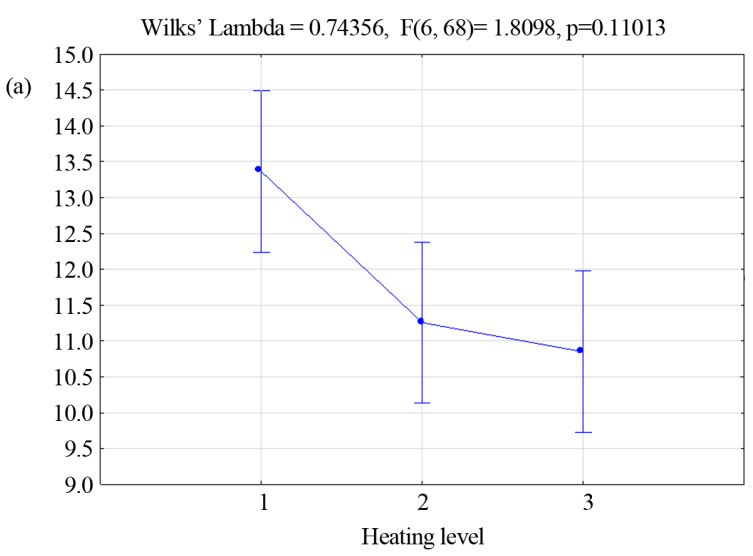

(b)
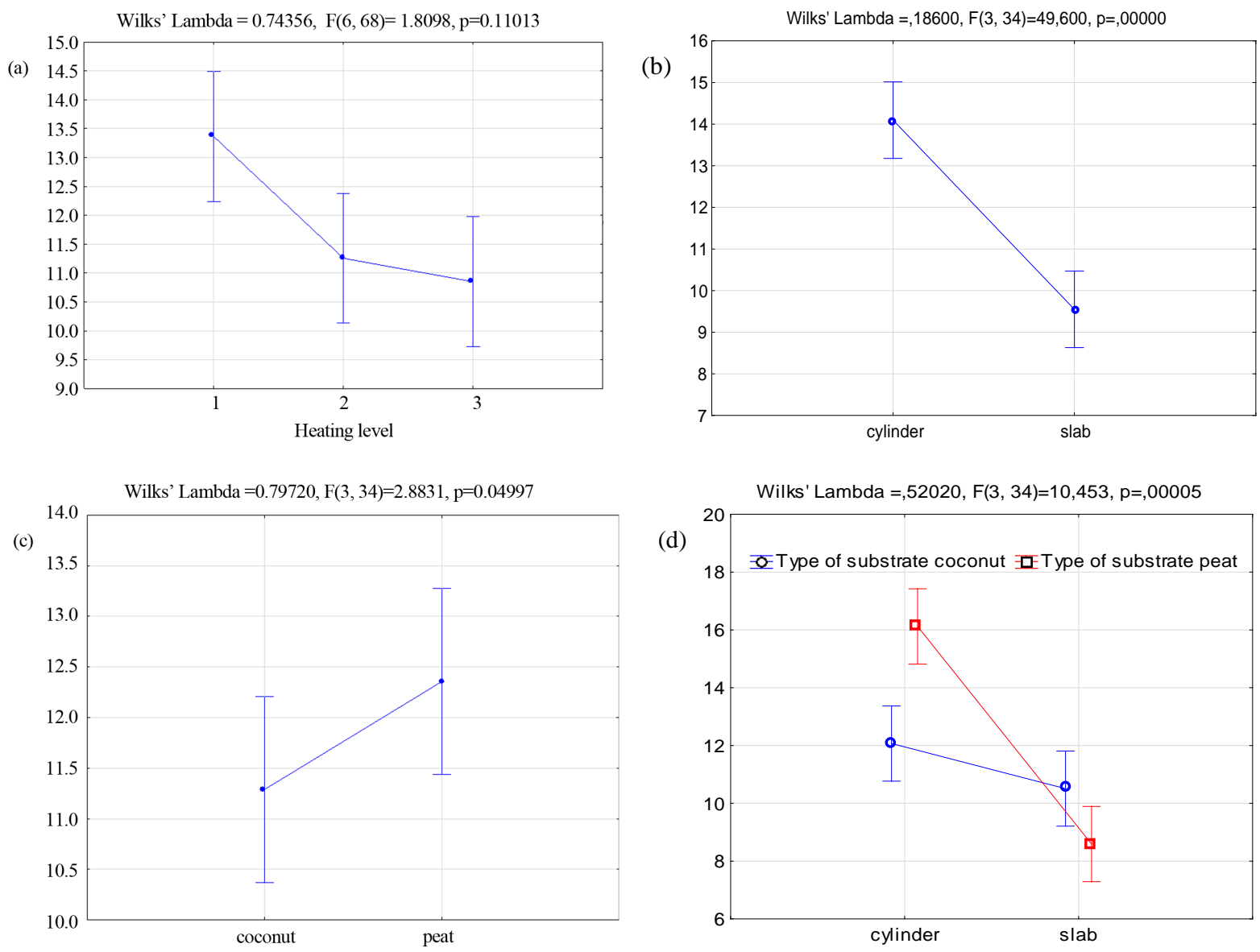

Figure 4. Expected marginal means of root volume $\left[\mathrm{cm}^{3} / \mathrm{L}\right.$ of soil] for the experimental factors: heating level (a), container shape (b), substrate type (c), container shape*substrate type (d); decomposition of effective hypotheses: columns mean 0.95 confidence intervals.

systems of tomato plants in slabs looked worse than those in cylinders. This might have also been caused by the excessive moisture in slabs (the system root is at the bottom part of a slab instead of being inside it). None of the examined factors significantly influenced the number of root tips and the root diameter. The substrate type had a significant effect on root parameters (Figure 4(c)). The better root growth on the peat substrate was caused by the higher organic and mineral composition of the peat in comparison with the coconut substrate. 


\subsection{Microbiological Analysis of the Rhizosphere Substrates}

Microbial counts depend on the environmental conditions, which include the type of growth substrate, moisture content, season of the year, the content of organic matter, temperature, crop species, and $\mathrm{pH}$ [8] [9]. The applied optimal conditions for the development of tomato ( $\mathrm{pH}$ of nutrient solution at 5.5) most probably had an advantageous effect on the growth of the analyzed groups of microorganisms and potential fluctuations in $\mathrm{pH}$ of substrates during culture contributed to the stronger development of individual groups. The population size of soil microorganisms is one of the parameters indicating microbiological activity of the colonized environment. Even the cultivar and its development phase determine the species composition and population size of microorganisms [10].

Much larger populations of bacteria and fungi were detected/recorded in the rhizosphere of tomato plants growing in the peat substrate than in the coconut substrate. This was related to the higher organic and mineral composition of the peat in comparison with the coconut substrate. The amount of organic matter in peat was at a level of $76.2 \%$, whereas coconut contained $55.2 \%$ of organic matter. Similarly, in the studies on the use of different organic substrates in the cultivation of tomato, Kleiber et al. [11] observed almost twice as many isolated bacteria in peat than in coconut fiber. The fungal population of the rhizosphere was unaffected by the container shape, but strongly depended on the thermal factor. The total number of fungi was depended on the container type and the growing substrate. However, the total number of bacteria was going up with increasing heating level, both in the peat and coconut fiber, and in both types of containers. These results revealed that the higher energy supply to the plants ( $2^{\text {nd }}$ and $3^{\text {rd }}$ heating levels) had a positive influence on bacterial multiplication and development, whereas those energy levels decreased the fungal formation and growth in the rhizosphere. Previous studies by Shadt et al. [12] on the seasonal growth dynamics of fungi and bacteria suggest that in comparison with bacteria the metabolism of fungi is greater at lower temperatures. Pietikäinen et al. [13] also observed an increase in the ratio of bacterial to fungal growth rate at higher temperatures. The optimum temperature for growth of the most fungi varied between $20^{\circ} \mathrm{C}-25^{\circ} \mathrm{C}$ [14]. In our studies, the most fungi were also found in the soil heated to approximately $20^{\circ} \mathrm{C}$ (Figure 6(b)).

The total numbers of bacteria and fungi in the rhizosphere samples were significantly higher in the peat substrate than in the coconut substrate (see Figures 5(a) and (b)). It might be caused by the different values of $\mathrm{pH}$ of substrates used in this experiment ( $\mathrm{pH}$ of peat was measured at 4.9 and $\mathrm{pH}$ of coconut fibre - 6.7). The samples of coconut rhizosphere soil contained much more beneficial bacteria producing spores in regard to the peat medium (Figure 5(c)). The total number of bacteria was going up with increasing soil temperature for samples taken from the coconut slabs, peat slabs and peat cylinders. It was only decreasing for coconut cylinders (Figure 5(a)). No significant impact of the container shape on the fungal and bacterial populations was recorded.

(a)
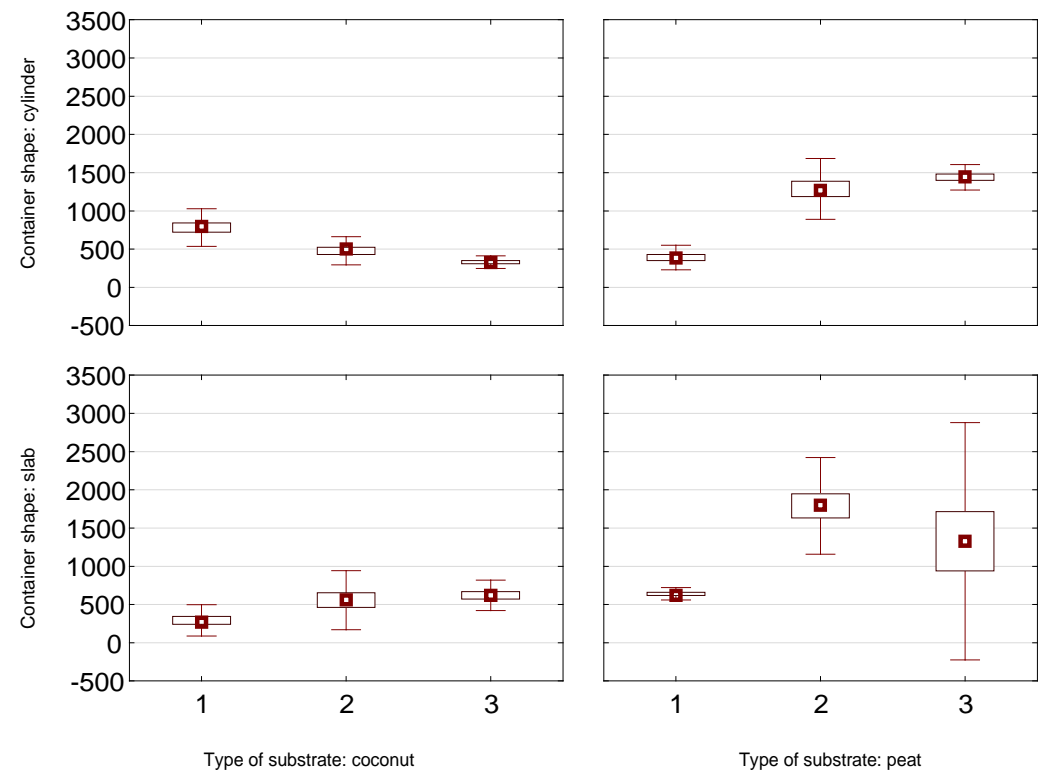
(b)
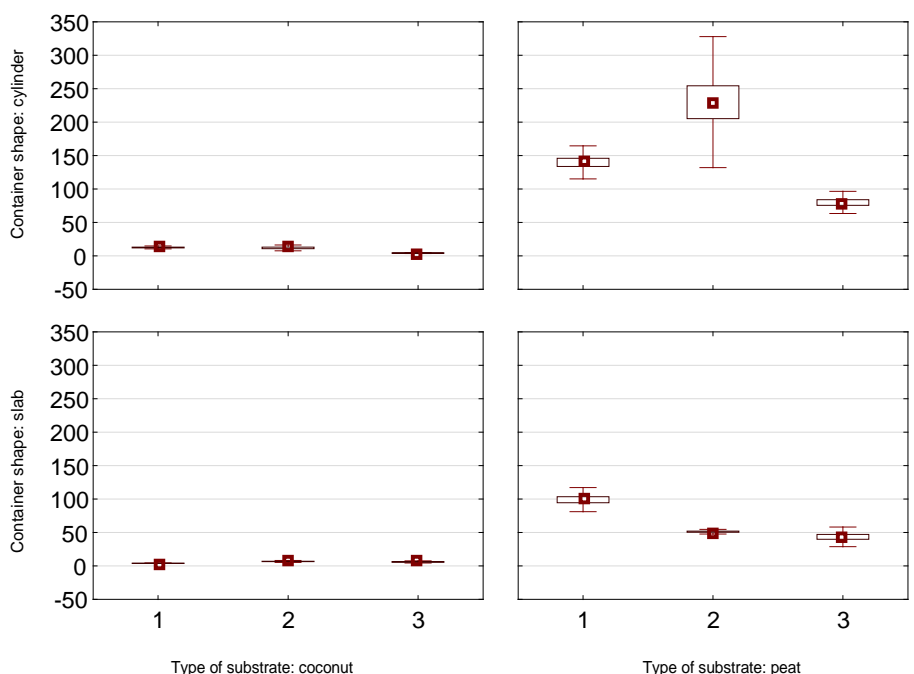

(c)
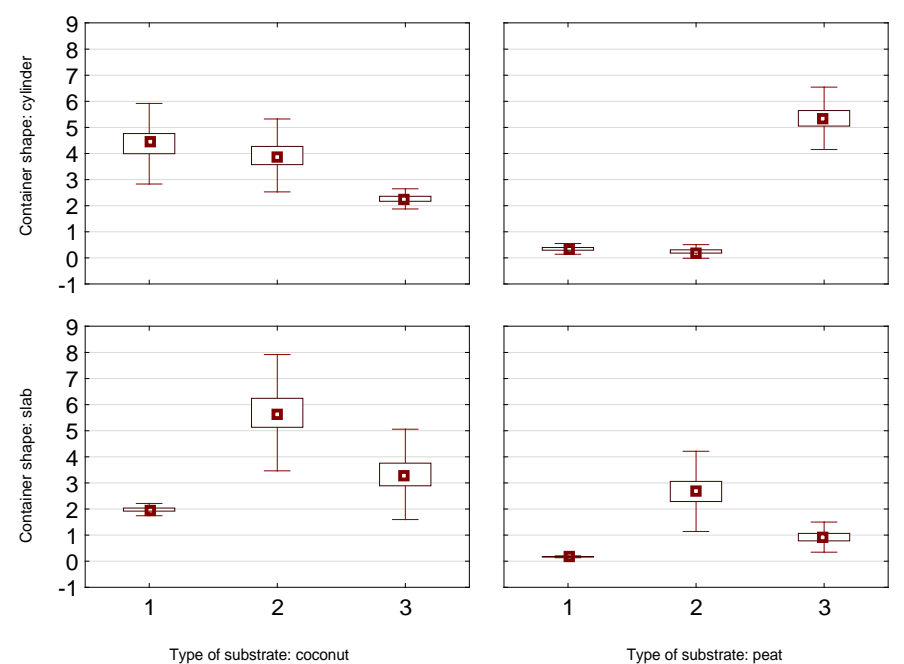

(d)
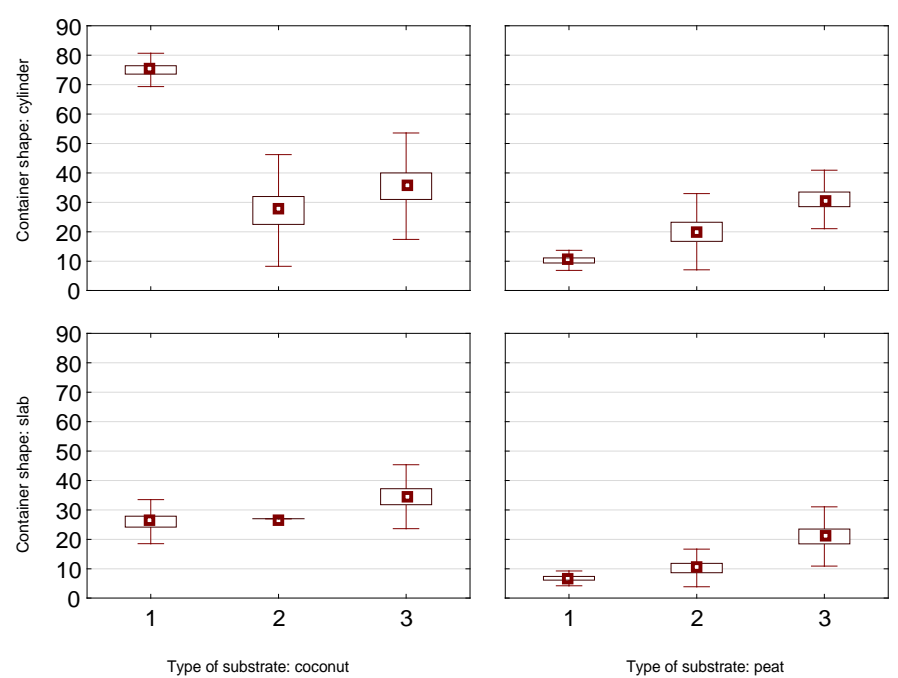

Figure 5. Expected marginal means of microorganisms (bacteria and fungi) $\left(\mathrm{CFU} \times 10^{3}\right.$ per $\mathrm{g}^{-1}$ of fresh soil) from May rhizosphere soils at different heating levels: (a) total number of bacteria (b) total number of fungi, (c) number of bacteria producing spores and (d) actinomycetes. 
Wilks' Lambda $=0.79405 ; F(18,503,95)=2.3783 ; p=0.00120$

(a)

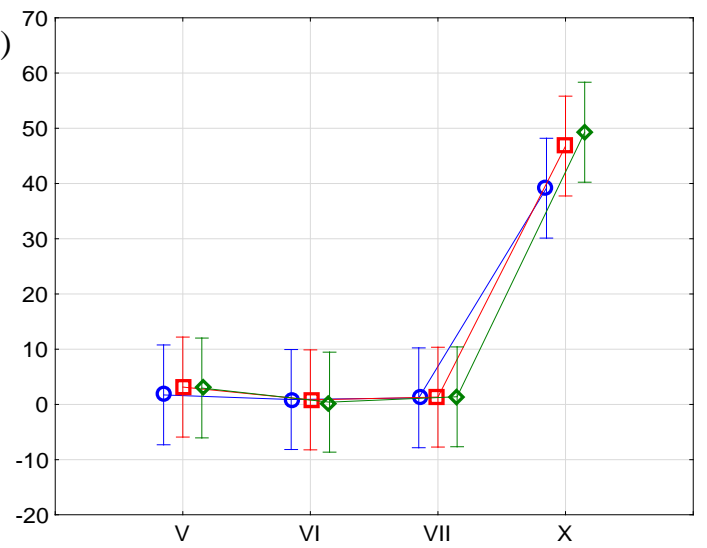

(c)

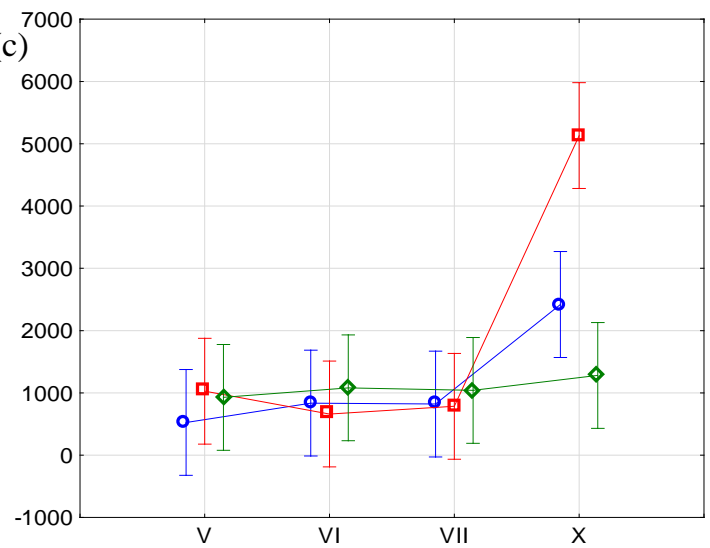

Control level $-1^{\text {st }}$ heating heating level (b)

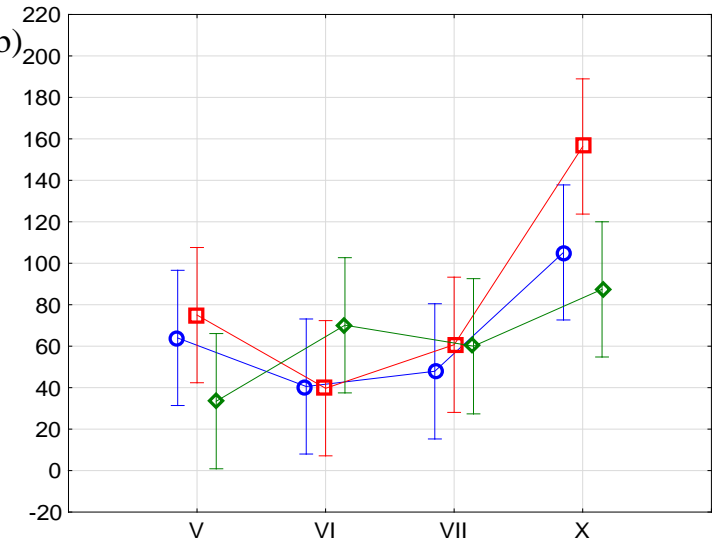

(d)

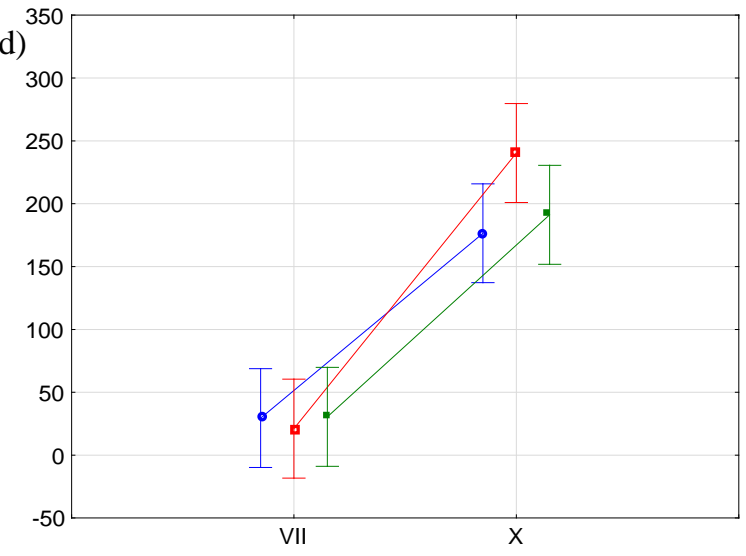

它 $2^{\text {nd }}$ heating level $\mp 3^{\text {rd }}$ level

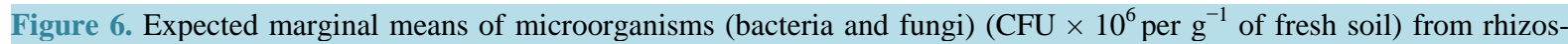
phere soils at different heating levels during different months (or plant development phases): (a) total number of bacteria (b) total number of fungi, (c) number of bacteria producing spores, (d) actinomycetes; V-May, VI-June, VII-July, $\mathrm{X}$-October; decomposition of effective hypotheses; vertical columns mean 0.95 confidence intervals (independent factors: heating level and time of soil samples collection).

The number of actinomycetes was increasing with increasing soil temperature (Figure 5(d)) with the exception of the plant roots/rhizosphere in the coconut cylinders. These results correspond well with those of Goodfellow and Williams [15], who observed the most efficient growth of Actinomycetes at $25^{\circ} \mathrm{C}-30^{\circ} \mathrm{C}$.

An increased temperature (reaching up even to $40^{\circ} \mathrm{C}$ ) and an insufficient moisture content, which is frequently observed in the hot summer months (VI - VII) in the greenhouse had a significant effect on the unchangeable and similar number of microorganisms inhabiting the substrates. These high temperatures in the greenhouse slightly reduced the activity of microorganisms in peat and coconut substrates (it could be caused by inactivation of some enzymes). Stapleton and De Vay [16] and Membre et al. [17] observed a decrease in the number of isolated microorganisms in substrates heated to about $45^{\circ} \mathrm{C}$.

This effect was visible in the unchanging population of bacteria and fungi (Figure 6). Lower temperatures in the autumn months (IX - X) (giving more favorable conditions for microorganisms development) could have lead to increase of microbial activity. It was associated with an increase in their population numbers (for example Figure $6(\mathrm{~d})$ ). The impact of external temperature on the population of microorganisms were clearly visible in October samples where the heat visibly influenced the number of bacteria and fungi. The highest populations of bacteria, bacteria producing spores, actinomycetes and fungi were noticed at the second heating level for October rhizosphere samples and the lowest-at the third heating level. This result suggests that in October the second heating level was the most optimal for the development of these groups of microorganisms. 


\subsection{Results of Nematological Analysis of Soil Samples}

Soil samples for nematological analysis were taken at the end of May 2012. Amongst the known trophic groups of nematodes in a tomato cultivar only individuals belonging to the groups of bacterivorous, fungivorous and predatory nematodes were found. There were found mostly individuals belonging to the families feeding on bacteria in slab cultivations (see results in Table 1). The individuals coming from the Aphelenchoididae family (Aphelenchoides sp) were the only representatives of nematodes feeding on fungi. Besides fungivorous nematodes from the Aphelenchoididae family, individuals from the Tylenchidae family were also recorded in the rhizosphere of plants growing in peat cylinders. Moreover, predatory nematodes deriving from the family Aphelenchoididae (Seinura sp) appeared in this cultivation type as well (Figure 7), but not a lot.

\section{Conclusions}

The study has shown that heating the substrates limited the root growth of tomato plants. Root morphological parameters of control plants were significantly higher than the parameters of plant roots growing on heated soil. Generally, all plants at the third heating level gave much higher first weekly crops than the ones at the lower heating level, but then there were no significant differences in the total yield for all experimental plants. Plants growing in peat slabs at the third heating level gave the highest first weekly crop what can be very important from the producer point of view.

On the base of the obtained results the below conclusions are stated:

The numbers of bacteria and fungi were significantly higher in the peat substrate than in a coconut fibre.

The population of bacteria was increasing with an increase in the substrate temperature, apart from the coconut cylinders.

The number of bacteria in a coconut substrate hasn't changed significantly with an increased substrate temperature.

The container type had no significant effect on the populations of bacteria and fungi.

Total fungi decreased with increasing peat temperature.

Table 1. Nematode occurrence in the rhizosphere of tomato plants versus the soil type and the heating level.

\begin{tabular}{|c|c|c|c|c|}
\hline \multirow{2}{*}{$\begin{array}{l}\text { Containers with } \\
\text { substrate types }\end{array}$} & \multirow{2}{*}{ Heating level } & \multicolumn{3}{|c|}{ Family } \\
\hline & & bacterivorous & fungivorous & Predatory \\
\hline \multirow{3}{*}{$\begin{array}{l}\text { Slabs with } \\
\text { coconut fibre }\end{array}$} & 3 & $\begin{array}{l}\text { Rhabditidae, Neodiplogasteridae, } \\
\text { Diplogasteridae, Cephalobidae }\end{array}$ & - & - \\
\hline & 2 & $\begin{array}{c}\text { Rhabditidae, Neodiplogasteridae, } \\
\text { Diplogasteridae }\end{array}$ & - & - \\
\hline & 1 -Control & $\begin{array}{l}\text { Rhabditidae, Neodiplogasteridae, } \\
\text { Diplogasteridae, Cephalobidae }\end{array}$ & - & - \\
\hline \multirow{3}{*}{ Slabs with peat } & 3 & $\begin{array}{l}\text { Rhabditidae, Neodiplogasteridae, } \\
\text { Diplogasteridae, Cephalobidae }\end{array}$ & Aphelenchoididae & - \\
\hline & 2 & $\begin{array}{l}\text { Rhabditidae, Neodiplogasteridae, } \\
\text { Diplogasteridae, Cephalobidae }\end{array}$ & - & - \\
\hline & 1 -Control & $\begin{array}{l}\text { Rhabditidae, Neodiplogasteridae, } \\
\text { Diplogasteridae, Cephalobidae }\end{array}$ & Aphelenchoididae & - \\
\hline \multirow{3}{*}{$\begin{array}{l}\text { Cylinders with } \\
\text { coconut fibre }\end{array}$} & 3 & Rhabditidae, Neodiplogasteridae & - & - \\
\hline & 2 & Rhabditidae, Neodiplogasteridae & - & - \\
\hline & 1 -Control & $\begin{array}{l}\text { Rhabditidae, Neodiplogasteridae, } \\
\text { Cephalobidae }\end{array}$ & Aphelenchoididae & Aphelenchoididae \\
\hline \multirow{3}{*}{ Cylinders with peat } & 3 & $\begin{array}{c}\text { Rhabditidae, Neodiplogasteridae, } \\
\text { Diplogasteridae, Cephalobidae }\end{array}$ & $\begin{array}{l}\text { Aphelenchoididae } \\
\text { Tylenchidae }\end{array}$ & Aphelenchoididae \\
\hline & 2 & $\begin{array}{l}\text { Rhabditidae, Neodiplogasteridae, } \\
\text { Diplogasteridae, Alaimidae }\end{array}$ & Aphelenchoididae & Aphelenchoididae \\
\hline & 1 -Control & $\begin{array}{c}\text { Rhabditidae, Neodiplogasteridae, } \\
\text { Cephalobidae }\end{array}$ & $\begin{array}{l}\text { Aphelenchoididae } \\
\text { Tylenchidae }\end{array}$ & - \\
\hline
\end{tabular}



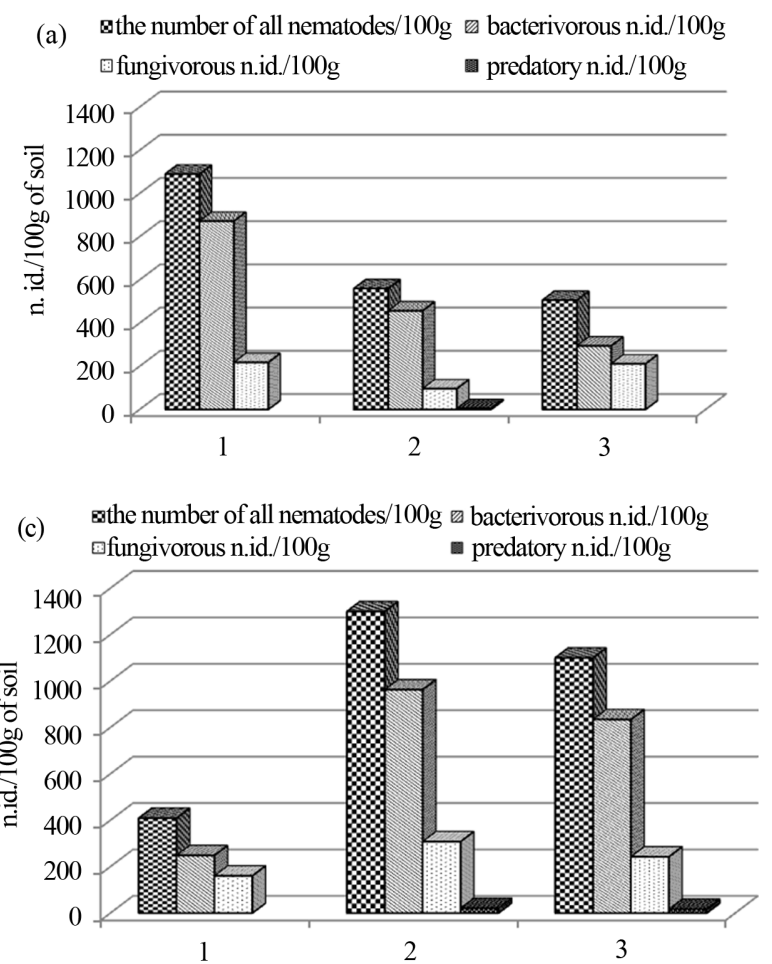
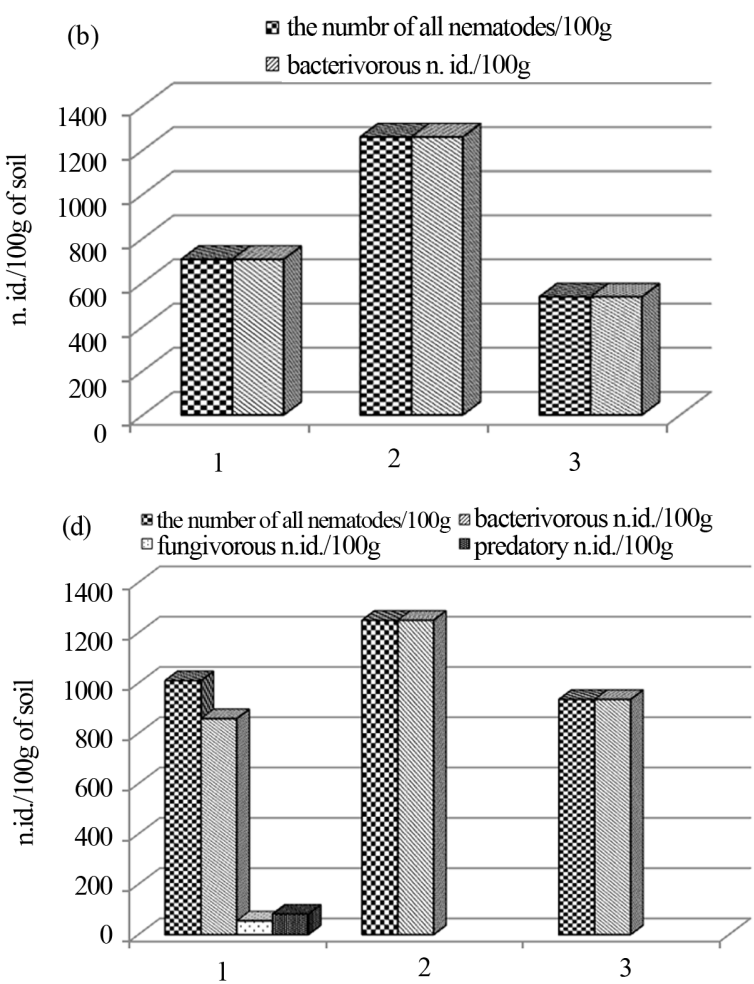

Figure 7. The number of individuals (per 100g of soil) and groups of nematodes: in slabs filled with peat (a) and coconut fibre (b); in cylinders filled with peat (c) and coconut fibre (d) against the heating level. 1—control level, 2-second heating level, 3-third heating level.

A much higher number of beneficial bacteria producing spores were noted in the coconut substrate.

Summer months limited the development of the population of bacteria and fungi.

The total number of bacteria and fungi was highest at three energy levels for samples collected in October.

The largest/biggest number of nematodes was recorded at the second energy level, with the exception of cultivation carried out in a peat substrate in slabs, where most of nematodes were found at the control level.

The interaction of the container type and substrate type significantly influenced the morphology of the root system.

Plants growing in the cylinders on peat substrates had the highest root growth characteristics.

Further investigations on the number of beneficial microorganisms depending on the heating level and the type of the growth substrate will be continued to answer which heating level is the most favorable for the development of these groups of microorganisms, e.g. types of bacteria (e.g. Azotobacter, Pseudomonas fluorescens) and fungi in the rhizosphere.

\section{Acknowledgements}

The work has been supported by the grant from the EU Regional Development Fund through the Polish Innovation Economy Operational Program, contract No. UDA-POIG. 01.03.01-10-115/09.

\section{References}

[1] Naika, S., van Lidt de Jeude, J., de Goffau, M., Hilmi, M. and van Dam, B. (2005) Cultivation of Tomato. Agrodok 17, (C) Agromisa Foundation and CTA, Wageningen.

[2] Bulluck III, L.R., Barker, K.R. and Ristaino, J.B. (2002) Influences of Organic and Synthetic Soil Fertility Amendments on Nematode Trophic Groups and Community Dynamics under Tomatoes. Applied Soil Ecology, 21, $233-250$. http://dx.doi.org/10.1016/S0929-1393(02)00089-6.

[3] Kurpaska, S. (2000) System ogrzewania podłoża ogrodniczego ciepłym powietrzem. Analiza teoretyczna i weryfikacja eksperymentalna. Zeszyty Naukowe AR w Krakowie, Z. 269. 
[4] Carrijo, O.A., Vidal, M.C., dos Reis, N.V.B., de Souza, R.B. and Makishima N. (2004) Tomato Crop Production under Different Substrates and Greenhouse Models. Horticultura Brasileira, Brasília, 22, 05-09.

[5] Hallman, E. and Kobryń, J. (2002). Wpływ rodzaju pod-łoża na plonowania pomidora drobnoowocowego (Lycopersicon esculentum var. cerasiforme) w uprawie szklarniowej. Zeszyty Problemowe Postępów Nauk Rolniczych, 485, 117124.

[6] Shinohara, Y., Hata, T., Marui, T., Hojo, M. and Ito, T. (1999) Chemical and Physical Properties of the Coconut-Fiber Substrate and the Growth and Productivity of Tomato. Acta Horticulturae, 481, 145-149.

[7] Ostrowska, A., Gawliński, S. and Szczubiałka, Z. (1991) Metody analizy i ocena właściwości gleb i roślin, Instytut Ochrony Środowiska, Warszawa, Poland (in Polish).

[8] Kucharski, J., Karuzo-Wankiewicz, L. and Kuczyńska, L. (2004). Effect of Soil Contamination Starane 250 EC on the Microbiological Properties. Acta Agraria et Silvestria/Agraria, 42, 257-263 (in Polish).

[9] Martyniuk, S., Księżniak, A., Jończyk, K. and Kuś, J. (2007) Microbiological Characteristics of Soil under Winter Wheat Grown in Ecological and Conventional System. Journal of Research and Applications in Agricultural Engineering, 52 (in Polish).

[10] Woch, T., Collective Work (2007) Vademecum Soil Classifier, Puławy (in Polish).

[11] Kleiber, T., Markiewicz, B. and Niewiadomska, A. (2012) Organic Substrates for Intensive Horticultural Cultures: Yield and Nutrient Status of Plants, Mirobiological Parameters of Substrates. Polish Journal of Environmental Studies, 21, 1261-1271.

[12] Schadt, C.W., Martin, A.P., Lipson, D.A. and Schmidt, S.K. (2003) Seasonal Dynamics of Previously Unknown Fungal Lineages in Tundra Soils. Science, 301, 1359-1361.http://dx.doi.org/10.1126/science.1086940

[13] Pietikäinen, J., Pettersson, M. and Bååth, E. (2005) Comparison of Temperature Effects on Soil Respiration and Bacterial and Fungal Growth Rates. FEMS Microbiology Ecology, 52, 49-58. http://dx.doi.org/10.1016/j.femsec.2004.10.002

[14] Watanabe, T. (2010) Pictorial Atlas of Soil and Seed Fungi. Third Edition. CRC Press, Boca Raton. http://dx.doi.org/10.1201/EBK1439804193

[15] Goodfellow, M. and Williams, S.T. (1983) Ecology of Actinomycetes. Annual Review of Microbiology, 37, $189-216$. http://dx.doi.org/10.1146/annurev.mi.37.100183.001201

[16] Stapleton, J.J. and DeVay, J.E. (1982) Effect of Soil Solarization on Populations of Selected Soilborne Microorganisms and Growth of Deciduous Fruit Tree Seedlings. Phytopathology, 72, 323-326.

[17] Membre, J.M., Leporq, B., Vialette, M., Mettler, E., Perrier, L., Thuault, D. and Zwietering, M. (2005) Temperature Effect on Bacterial Growth Rate: Quantitative Microbiology Approach Including Cardinal Values and Variability Estimates to Perform Growth Simulations on/in Food. International Journal of Food Microbiology, 100, 179-186. http://dx.doi.org/10.1016/j.ijfoodmicro.2004.10.015 